\title{
KAJIAN USAHA PENGGEMUKAN SAPI BALI DI KABUPATEN MAROS DAN BARRU, PROVINSI SULAWESI SELATAN
}

\section{Assessment Analysis of Bali Cattle Fattening In Maros and Barru District, South Sulawesi Province}

\author{
A.R. Tondok, N. Qomariyah dan M. Sariubang \\ Balai Pengkajian Teknologi Pertanian (BPTP) Sulawesi Selatan, Makassar \\ e-mail: abigael.rantetondok@gmail.com
}

Received: 2 April 2021; Accepted: 10 Mei 2021; Published: 25 Juni 2021

\begin{abstract}
ABSTRAK
Permasalahan yang dihadapi penggemukan sapi di Kabupaten Maros dan Barru antara lain rendahnya pengetahuan penyusunan pakan murah yg berkualitas dan kelembagaan ekonomi petani yang belum berkembang. Tujuan penelitian untuk mengetahui kelayakan usahatani penggemukan sapi dengan memanfaatkan pakan lokal di Kabupaten Maros dan Kabupaten Barru. Metode dasar yang digunakan dalam penelitian ini adalah metode deskriptif, penentuan sampel secara purposive dan analisis data dengan analisis parsial usahatani selama satu kali proses produksi (3 bulan) menggunakan pendekatan dengan rumus perhitungan: $\mathrm{Pd}=\mathrm{TR}-\mathrm{TC}$, dilanjutkan dengan $\mathrm{R} / \mathrm{C}$ ratio. Hasil pengkajian menunjukkan bahwa teknologi penggemukan sapi dengan pemberian pakan konsentrat menghasilkan pertambahan bobot badan (PBB) ratarata sebesar 0,6-07 kg/ekor/hr. Dalam tiga bulan penggemukan sapi Bali memberikan pendapatan bersih sebesar Rp. 1.069.854,-/ekor - Rp. 7.521.500,- per ekor dengan R/C sebesar 1,20-1,98 yang berindikasi bahwa usaha tersebut menguntungkan dan layak untuk diusahakan.
\end{abstract}

Kata kunci: Sapi bali, penggemukan, konsentrat

\section{ABSTRACT}

The problems faced by cattle fattening in Barru Regency include common knowledge of low-quality cheap feed preparation and underdeveloped farmer economist institutions. The research objective was to determine the feasibility of fattening cattle farming by utilizing local feed-in Maros and Barru Regency. The basic method used in this research is a descriptive method, purposive sampling, and data analysis with partial analysis of the farm during one production process ( 3 months) using an approach with the calculation formula: $P d=T R$ - $T C$, followed by the $R / C$ ratio. The results of the study indicate that the technology offattening cattle is capable of producing an average body weight gain (PBB) of 0.6-0.7 kg/head/day. So in a period of 3 months, Bali cattle fattening farming provides a net income to the farmer groups of Rp. 1.069.854-Rp. 7,521,500 per head with an $R / C$ of 1.20-1.98, which indicates that the business is profitable and feasible to run.

Keywords: Bali beef cattle, fattening, consentrate

\section{PENDAHULUAN}

Sektor peternakan memiliki peran penting dan strategis bagi Provinsi Sulawesi Selatan mengingat keberadaannya sebagai lumbung ternak di kawasan Timur Indonesia.
Adapun populasi ternak sapi di Sulawesi Selatan pada tahun 2018 sebesar 1,310,194 (BPS, 2018). Sapi potong merupakan komoditas andalan di daerah ini. Budidaya sapi potong diusahakan secara tradisional dengan pemberian pakan berupa jerami padi. Menurut Chanthakhoun et al., (2012) dan

Diterbitkan Oleh,

Unit Penelitian dan Pengabdian Masyarakat, Politeknik Pembangunan Pertanian Gowa

http://ejournal.polbangtan-gowa.ac.id 
Wanapat (2009) jerami padi merupakan serat penting bagi ruminansia di daerah tropis.

Peningkatan produktivitas ternak dapat dilakukan melalui pemilihan bibit unggul, manajemen pemeliharaan, pakan dan sistem perkandangan. Selain itu, produktivitas ternak sangat erat kaitannya dengan kualitas pakan yang diberikan. Kualitas pakan pada usaha penggemukan sapi secara tradisional kurang memperhatikan kebutuhan nutrisi ternaknya. Akibatnya, ternak mengkonsumsi pakan tidak sesuai dengan kebutuhan dan pertumbuhan ternak menjadi kurang optimal. Selain itu, kualitas pakan yang diberikan sangat rendah sehingga tidak mencukupi kebutuhan ternak. Oleh karena itu, teknologi formulasi pakan lokal sangat penting diketahui oleh peternak. Penerapan inovasi teknologi formulasi pakan merupakan salah satu cara dalam pemanfaatan sumber daya petani yang terbatas sesuai dengan kondisinya masing-masing. Dengan penerapan inovasi teknologi formulasi pakan murah diharapkan dapat meningkatkan efisiensi produksi pada penggemukan sapi sekaligus meningkatkan pendapatan dan kesejahteraan peternak.

Pemberian pakan penguat (konsentrat) merupakan langkah yang baik untuk meningkatkan produktivitas usaha penggemukan sapi potong. Konsentrat (produk bijian dan butiran) serta bahan berserat (jerami atau rumput) merupakan komponen atau penyusun ransum (Blakely dan
Bade, 1991). Penggunaan konsentrat dapat meningkatkan laju pertumbuhan ternak dan meningkatkan pendapatan dan keuntungan petani kecil (Ba et al., 2008). Penelitian bertujuan untuk mengetahui kelayakan usahatani penggemukan sapi dengan memanfaatkan pakan lokal di Kabupaten Maros dan Barru.

\section{METODE PENELITIAN}

Kegiatan ini dilaksanakan di Desa Pattiro Deceng, Kecamatan Camba, Kabupaten Maros dan Desa Tompo, Kecamatan Barru, Kabupaten Barru. Kegiatan ini dilakukan dilahan petani dengan pendekatan on farm research dan pendekatan pedesaan secara partisipatif yaitu melibatkan petani secara langsung sejak perencanaan, pengamatan dan penilaian terhadap kinerja teknologi. Adapun petani yang terlibat tergabung dalam kelompok tani Pattiro Deceng dan Tompo 2, dengan paket teknologi meliputi: bakalan (sapi Bali) untuk penggemukan adalah sapi jantan dewasa umur 2 2,5 tahun; pakan penguat (konsentrat) pemberian $1 \%$ dari berat badan, sedangkan pakan hijauan pemberian $10 \%$ dari berat badan serta perkandangan ternak secara komunal. Pakan hijauan terdiri dari rumput lapang. Bahan pakan yang digunakan yaitu dedak padi, tongkol jagung, bungkil kelapa, tepung ikan dan mineral mix. Komposisi pakan yang digunakan diuraikan pada tabel 1 dan 2.

Tabel 1. Formulasi pakan penguat pada penggemukan sapi di Kabupaten Maros

\begin{tabular}{lcc}
\hline \multicolumn{1}{c}{ Bahan } & Komposisi $(\%)$ \\
\hline Dedak Padi & 58,9 \\
Bungkil Kelapa & 35,3 \\
Tepung ikan & 5,2 \\
Mineral Mix & Total & 0,6 \\
& & 100 \\
\hline
\end{tabular}

\section{Jenis Data dan Informasi yang Dikumpulkan}

Data primer dikumpulkan dari hasil observasi dan wawancara langsung menggunakan kuesioner. Data aspek finansial yang dikumpulkan meliputi penggunaan dan biaya input sarana produksi penggemukan yaitu bakalan sapi, pakan, obat-obatan, serta penggunaan biaya input tenaga kerja. Metode dasar yang digunakan dalam penelitian ini adalah metode deskriptif, penentuan sampel secara purposive dan analisis data dengan analisis parsial usahatani selama satu kali proses 
produksi (3 bulan) menggunakan pendekatan dengan rumus perhitungan: $\mathrm{Pd}=\mathrm{TR}-\mathrm{TC}$, dilanjutkan dengan $\mathrm{R} / \mathrm{C}$ ratio. Keterangan : $\mathrm{Pd}=$ Pendapatan bersih $; \mathrm{TR}=$ Total penerimaan $; \mathrm{TC}=$ Total biaya yang terdiri atas biaya tetap dan biaya tidak tetap ; Py = Harga per satuan input Selanjutnya perhitungan $\mathrm{R} / \mathrm{C}$ ratio, merupakan perbandingan antara penerimaan dan biaya yang dikeluarkan (Soekartawi, 2002).

Tabel 2. Formulasi pakan penguat pada penggemukan sapi di Kabupaten Barru

\begin{tabular}{|c|c|}
\hline Bahan & Komposisi (\%) \\
\hline Dedak Padi & 50 \\
\hline Tongkol jagung & 30 \\
\hline Bungkil Kelapa & 12 \\
\hline Tepung ikan & 7 \\
\hline Mineral Mix & 1 \\
\hline Total & 100 \\
\hline
\end{tabular}

\section{HASIL DAN PEMBAHASAN}

\section{Karakteristik Sumberdaya Alam}

Karakteristik sumberdaya alam meliputi : temperatur, kelembaban, dan curah hujan. Kecamatan Barru memiliki temperatur yang relatif baik bagi pertumbuhan ternak. Curah hujan di wilayah ini juga cukup tinggi yaitu $800 \mathrm{~mm} /$ tahun sehingga berkorelasi tinggi dengan ketersediaan pakan hijauan. Kegiatan penggemukan sapi mulai dilakukan pada bulan Desember sampai dengan bulan Juli, karena dapat menjamin kualitas maupun kuantitas pakan yang diberikan pada masa penggemukan sehingga akan memberikan pertumbuhan optimal serta mempercepat periode produksi. Hal ini akan menjadi lebih efisien baik dari tenaga ataupun biaya lain dibutuhkan dalam proses penggemukan.

Tabel 3. Pertambahan bobot badan sapi penggemukan di Kabupaten Maros

\begin{tabular}{cccc}
\hline Nomor Sapi & $\begin{array}{c}\text { Berat sapi awal } \\
(\mathrm{kg})\end{array}$ & $\begin{array}{c}\text { Berat Sapi akhir } \\
(\mathrm{kg})\end{array}$ & $\begin{array}{c}\text { Peningkatan Bobot Badan } \\
(\mathrm{kg} / \mathrm{hari})\end{array}$ \\
\hline 1 & 186 & 235 & 0,54 \\
2 & 195 & 243 & 0,53 \\
3 & 162 & 227 & 0,72 \\
4 & 262 & 340 & 0,87 \\
5 & 131 & 178 & 0,52 \\
6 & 294 & 340 & 0,51 \\
7 & 136 & 186 & 0,56 \\
8 & 124 & 184 & 0,67 \\
9 & 271 & 344 & 0,81 \\
10 & 130 & 187 & 0,63 \\
11 & 95 & 124 & 0,32 \\
12 & 97,5 & 143,5 & 0,51 \\
Rata-Rata & 173,6 & 227,6 & 0,6 \\
\hline
\end{tabular}

Diterbitkan Oleh, 
Desa Pattiro Deceng memiliki potensi pertanian, hortikultura, peternakan, perkebunan dan kehutanan. Seperti pada komoditi padi memiliki luas tanam sebesar 336 ha, luas panen 336 ha dan produksi mencapai 7,16 ton/ha, sedangkan pada komoditi peternakan populasi sapi potong berjumlah 550 ekor, kerbau 215 ekor, kuda 85 ekor dan kambing 83 ekor (BPP, 2008).

\section{Aplikasi paket teknologi}

Komposisi pakan penggemukan berdasarkan Tabel 1 dan Tabel 2 memiliki kandungan protein kasar sebesar 16,10\% dengan harga pakan berkisar antara Rp 2.550/kg-Rp. $3.575 / \mathrm{kg}$. Harga ini lebih murah $68 \%$ dibanding dengan harga pakan yang ada di pasaran saat ini yaitu Rp. 8.000/kg. Berdasarkan Tabel 3 dan Tabel 4 tampak bahwa rata-rata berat sapi pada awal penggemukan sebesar 173,6 kg/ekor-190,6 $\mathrm{kg} / \mathrm{ekor}$. Setelah 3 (tiga) bulan pemeliharaan ratarata berat badannya meningkat menjadi 227,6 $\mathrm{kg} / \mathrm{ekor}$ - 253,3 kg/ekor. Adapun pertambahan bobot badan rata-ratanya sebesar 0,6-0,7 $\mathrm{kg}$ /ekor/hari.

Tabel 4. Pertambahan bobot badan sapi penggemukan di Kabupaten Barru

\begin{tabular}{cccc}
\hline Nomor Sapi & $\begin{array}{c}\text { Berat Sapi Awal } \\
(\mathrm{kg})\end{array}$ & $\begin{array}{c}\text { Berat Sapi Akhir } \\
(\mathrm{kg})\end{array}$ & $\begin{array}{c}\text { Peningkatan Bobot Badan } \\
(\mathrm{kg} / \mathrm{hari})\end{array}$ \\
\hline 1 & 211,5 & 263 & 0,57 \\
2 & 163 & 205 & 0,46 \\
3 & 160 & 224 & 0,71 \\
4 & 244 & 301 & 0,63 \\
5 & 134 & 253 & 1,32 \\
6 & 214,5 & 263,5 & 0,55 \\
7 & 171 & 214 & 0,48 \\
8 & 222 & 275 & 0,59 \\
9 & 183 & 273,5 & 1,01 \\
10 & 203 & 261 & 0,65 \\
Rata-Rata & 190,6 & 253,3 & 0,7 \\
\hline
\end{tabular}

Perbandingan perhitungan biaya yang dikeluarkan dan keuntungan yang diperoleh dari usaha penggemukan sapi disajikan pada Tabel 5 dan Tabel 6. Berdasarkan Tabel 5 terlihat bahwa total biaya yang dikeluarkan untuk memelihara 12 ekor sapi selama 3 (tiga) bulan pemeliharaan sebesar Rp. 70.177.750,- dengan keuntungan ratarata per ekor sebesar Rp. 1.069.854,-. Sementara, biaya yang dikeluarkan untuk memelihaaran sapi dengan menggunakan teknologi petani sebesar Rp. 11.660.000,- dengan keuntungan rata-rata per ekor sebesar Rp. 230.000,- jauh lebih kecil dibandingkan keuntungan yang diperoleh peternak kooperator dengan teknologi introduksi. Dari hasil analisis penggemukan sapi dengan pemberian pakan konsentrat memberikan keuntungan yang lebih tinggi dari pada tanpa pemberian pakan konsentrat.

Adapun hasil analisa usahatani penggemukan sapi di Kabupaten Barru disajikan pada Tabel 6. Dari Tabel 6 menunjukkan bahwa biaya yang dikeluarkan untuk memelihara satu ekor sapi dalam teknologi penggemukan sapi selama 3 bulan adalah sebesar Rp. 7.676.500,-. Bobot Badan di akhir pemeliharaan sebesar 253,3 kg dengan estimasi harga jual sebesar Rp. 60.000/kg, maka penerimaan petani sebesar Rp. 15.198.000. Dari selisih penerimaan dan biaya yang dikeluarkan oleh peternak, mereka mendapatkan keuntungan sebesar Rp. 7.521.500. Hasil pengenalan teknologi pada penggemukan sapi menunjukkan bahwa nilai R/C rasio yang diperoleh sebesar 1,98, sedangkan teknologi petani diperoleh nilai rasio R/C sebesar 1,44 . 
DOI: 10.52625/j-agr-sosekpenyuluhan.v17i1.189

Tabel 5. Analisis usahatani penggemukan sapi di Kabupaten Maros

\begin{tabular}{|c|c|c|c|c|c|c|c|}
\hline \multirow{2}{*}{ No } & \multirow{2}{*}{ Uraian } & \multicolumn{3}{|c|}{ Teknologi introduksi } & \multicolumn{3}{|c|}{ Teknologi petani } \\
\hline & & Vol & Harga & Nilai (Rp) & Vol & Harga & Nilai (Rp) \\
\hline A. & Biaya & & & & & & \\
\hline 1. & Harga Bakalan & $2083,2 \mathrm{~kg}$ & 30.000 & 62.496 .000 & $373 \mathrm{~kg}$ & 30.000 & 11.190 .000 \\
\hline \multirow{3}{*}{2.} & Biaya Pakan : & & & & & & \\
\hline & Konsentrat & $1.080 \mathrm{~kg}$ & 3.575 & 3.861 .000 & $200 \mathrm{~kg}$ & 1.500 & 300.000 \\
\hline & Hijauan & $8.403 \mathrm{~kg}$ & 250 & 2.100 .750 & $600 \mathrm{~kg}$ & 250 & 150.000 \\
\hline 3. & Biaya Obat-obatan & 1 paket & 220.000 & 220.000 & 1 paket & 50.000 & 50.000 \\
\hline \multirow[t]{2}{*}{4.} & Biaya Pemeliharaan & 3 bulan & & 1.500 .000 & - & - & - \\
\hline & \multicolumn{2}{|c|}{ Jumlah Biaya } & & 70.177 .750 & & & 11.660 .000 \\
\hline B & Penerimaan & & & & & & \\
\hline 1. & Harga jual sapi & $2731,2 \mathrm{~kg}$ & 30.000 & 81.936 .000 & $404 \mathrm{~kg}$ & 30.000 & 12.120 .000 \\
\hline \multirow[t]{2}{*}{2.} & Harga jual kotoran sapi & $2.160 \mathrm{~kg}$ & 500 & 1.080 .000 & - & - & \\
\hline & \multicolumn{2}{|c|}{ Jumlah Penerimaan } & & 83.016 .000 & & & 12.120 .000 \\
\hline \multirow[t]{4}{*}{ C. } & Keuntungan & & & & & & \\
\hline & Total & & & 12.838 .250 & & & 460.000 \\
\hline & Rata-rata & & & 1.069 .854 & & & 230.000 \\
\hline & R/C Rasio & & & 1,183 & & & 1,039 \\
\hline
\end{tabular}

Keterangan : Pakan Konsentrat teknologi petani berupa dedak padi

Tabel 6. Analisis usahatani penggemukan sapi di Kabupaten Barru

\begin{tabular}{|c|c|c|c|c|c|c|c|}
\hline \multirow{2}{*}{ No } & \multirow{2}{*}{ Uraian } & \multicolumn{3}{|c|}{ Teknologi petani } & \multicolumn{3}{|c|}{ Teknologi introduksi } \\
\hline & & Vol & Harga & Nilai (Rp) & Vol & Harga & Nilai (Rp) \\
\hline A & Biaya Produksi & & & & & & \\
\hline \multirow[t]{10}{*}{1.} & Biaya Sarana Produksi & & & 6.710 .000 & & & 7.176 .500 \\
\hline & Sapi Bakalan & & & 6.000 .000 & & & 6.000 .000 \\
\hline & Dedak Halus & & & & $135 \mathrm{~kg}$ & 3.000 & 405.000 \\
\hline & T. Jagung & & & & $81 \mathrm{~kg}$ & 1.000 & 81.000 \\
\hline & Bungkil Kelapa & & & & $32,4 \mathrm{~kg}$ & 2.800 & 90.750 \\
\hline & Limbah ikan & & & & $18,9 \mathrm{~kg}$ & 5.000 & 94.500 \\
\hline & Mineral Mix & & & & $2,7 \mathrm{~kg}$ & 7.500 & 20.250 \\
\hline & Rumput/Hijauan & $1.350 \mathrm{~kg}$ & 500 & 675.000 & 900 & 500 & 450.000 \\
\hline & Jerami Padi & & & & & & \\
\hline & Obat-obatan & 1 paket & 35.000 & 35.000 & 1 paket & 35.000 & 35.000 \\
\hline \multirow[t]{2}{*}{2.} & Biaya Tenaga Kerja & & & 500.000 & & & 500.000 \\
\hline & Tenaga Kerja & $10 \mathrm{OH}$ & 50.000 & 500.000 & $10 \mathrm{OH}$ & 50.000 & 500.000 \\
\hline \multirow[t]{5}{*}{3.} & Total Biaya Produksi $(1+2)$ & & & 7.210 .000 & & & \\
\hline & & & & & & & 7.676 .500 \\
\hline & Penerimaan & & & & & & \\
\hline & Berat Rata-rata & $173,3 \mathrm{~kg}$ & 60.000 & 10.398 .00 & $253,3 \mathrm{~kg}$ & 60.000 & 15.198 .000 \\
\hline & & & & 0 & & & \\
\hline \multirow[t]{4}{*}{ B. } & Total Penerimaan & & & 10.398 .00 & & & 15.198 .000 \\
\hline & & & & 0 & & & \\
\hline & Keuntungan (B-A) & & & 3.188 .000 & & & 7.521 .500 \\
\hline & R/ C Ratio & & 1,44 & & & 1,98 & \\
\hline
\end{tabular}




\section{KESIMPULAN}

Dari hasil pengkajian ini dapat ditarik kesimpulan yaitu : inovasi teknologi penggemukan sapi Bali dengan formulasi pakan lokal dapat meningkatkan bobot sapi Bali. Usaha penggemukan sapi Bali dengan formula pakan lokal cukup menguntungkan dilaksanakan dengan memberikan kontribusi pendapatan bersih sebesar Rp. 1.069.854,-/ekor- Rp. 7.521.500,- dengan R/C sebesar 1,2-1,98 sehingga layak untuk diusahakan lebih lanjut.

\section{DAFTAR PUSTAKA}

Ba, N.X., Van, N.H., Ngoan, L.D., Leddin, C.M \& Doyle, P.T. 2008. Effects of amount of concentrate supplement on forage intake, diet digestibility and live weight gain in yellow cattle in Vietnam. Asian Australasian Journal of Animal Science, 21(12): 1736-1744. http://doi.org/ 10.5713/ajas.2008.80082

Blakely, J. dan Bade, D.H. 1991. Ilmu Peternakan. Edisi Keempat. Terjemahan : B. Srigandono. Universitas Gadjah Mada Press., Yogyakarta.
Badan Pusat Statistik. 2018. Populasi Sapi Potong menurut Provinsi [Internet]. [diunduh 4 Agustus 2020]. Tersedia dari: https://www.bps.go.id/linkTableDinamis/ view/id/1016.

Balai Penyuluhan Pertanian, Kehutanan. 2008. Rencana Kerja Penyuluhan Pertanian Kecamatan Camba, Kabupaten Maros. Maros.

Chanthakhun, V., Wanapat, M \& Berg, J. 2012 Level of crude protein in concentrate supplements influenced rumen characteristics, microbial protein synthesis and digestibility in swamp buffaloes (Bubalus bubalis). Livestock Science 144(3):197-204. 10.1016/j.livsci.2011.11.011

Soekartawi 2002. Teori Ekonomi Produksi. PT. Raja Grafindo Persada, Jakarta

Wanapat, . 2009. Potential uses of local feed resources for ruminants. Tropical Animal Health and Production, 41(7):1035-1049. http://doi.org/10.1007/s11250-008-9270$\mathrm{y}$. 